\title{
EVALUATION OF REVEGETATION TECHNIQUES FOR ROADSIDE CONSTRUCTION SITES
}

\author{
George HILVERS, Leslie HOPKINSON, Eric DAVIS \\ Civil and Environmental Engineering, West Virginia University, PO Box 6103, \\ 26506 Morgantown, WV, USA
}

Submitted 19 Feb. 2016; accepted 27 Sept. 2016

\begin{abstract}
Vegetation is often used to control erosion on right-of-way construction sites, but disturbed conditions provide challenges. This research evaluated the impact of common techniques for preparing seedbeds. The study assessed the use of topsoil, and the use of a hydraulic erosion-control product was compared to straw. Experimental seed mixtures were evaluated to understand how native and non-native seeds performed. The intent was to identify critical practices to use in general seeding and mulching specifications. A plot study was conducted comparing vegetation established during one growing season. Treatments included combinations of seed mixture, topsoil treatment, and mulch types. Three seed mixtures were considered: (1) currently used mixture, (2) a warm-season experimental mixture, and (3) a cool-season experimental mixture. Plots with topsoil and no topsoil were compared, and both straw and hydraulic erosion control products were considered. Ground cover, compaction, and biomass were evaluated. Results suggest that alternative seed mixtures that include native and low-threat-level species can provide adequate cover to meet permitting requirements in the first growing season. The warm-season seed mixture provided less cover than the other two mixtures after eight days, but no differences were determined in ground cover among the three seed mixtures at the end of the growing season. Initial germination was improved with hydraulic mulch, but long-term cover was equivalent between hydraulic and straw mulch. Topsoil application would not be recommended if the soil contains undesirable species, and the use of organic amendment products may be more desirable than topsoil alone; however, specifications need to allow the use of these products.
\end{abstract}

Keywords: roadside vegetation, bed preparation, ground cover, topsoil, mulch, environmental sustainability.

\section{Introduction}

Preventing soil erosion during road construction in mountainous areas is often a challenge. Roads are constructed as a series of cuts and fills, the cuts often have steep slopes and narrow benches, and the rock fills are typically moderately sloping, compacted, and composed of unconsolidated material (Rentch et al. 2005). To prevent soil erosion, state agencies typically specify the type of vegetative cover and reclamation procedures (e.g., PennDOT 1998; NCDOT 2003; VDOT 2007; WVDOH 2010). These specifications are often general, making it difficult to establish vegetation in mountainous terrain.

The most common erosion-control practice is to establish grass, which can reduce erosion by up to $95 \%$ compared to a bare surface (Pan, Shangguan 2006). Applying vegetative cover is often problematic because mountain soils are often mixed with parent material (Rentch et al. 2005). Therefore, soils may be highly acidic and have low nutrient content and high salt levels. Steep slopes and compaction resulting from construction practices are also challenges in erosion control (Hargett et al. 1982; Coppin, Richards 1990; Salon, Miller 2012; Haan et al. 2012).

Faced with the physical and chemical challenges of recreating ground cover in mountainous areas, fertilizer, topsoil, and mulch are added when seeding to help establish vegetation. Typically, the seedbed is prepared by stockpiling topsoil and removing vegetative debris and rocks. Topsoil should have an optimum $\mathrm{pH}$ of 5.5 to 7.5 , organic matter greater than or equal to $2 \%$, soluble salts less than $0.5 \mathrm{dS} / \mathrm{m}$, and nutrient (N-P-K) concentrations (Salon, Miller 2012). However, often the stockpiled topsoil does not meet these ideal levels. For example, topsoil applied at roadside construction sites in West Virginia can have organic matter as low as 1.5\% (WVDOH 2010), and the topsoil might not be suitable for establishing vegetation.

Corresponding author: Leslie Hopkinson

E-mail: leslie.hopkinson@mail.wvu.edu 
In addition to the application of topsoil, mulch is applied during seeding to prevent weeds, reduce evaporation, enrich the soil, moderate surface temperatures, and reduce erosion (Gray, Sotir 1996; Steinfeld et al. 2007; Dunifon et al. 2011; Storey et al. 2011). Straw is commonly used as an inexpensive mulch but has a short life-span and can be redistributed by winds (Robichaud et al. 2013). Hydraulic erosion-control products may help overcome these deficiencies but typically are expensive.

Another concern along highway corridors - the spread of invasive species (Mortensen et al. 2009) - suggests that highway agencies need to promote native species (Rentch et al. 2005). Although the use of native species in revegetation projects has been evaluated (Brindle 2002; Skousen, Venable 2008; Bochet et al. 2010), native species are uncommon in highway seed mixtures (e.g., WVDOH 2010). Bochet et al. (2010) showed, however, that native seed mixtures could produce twenty times the ground cover of conventional seed mixtures. Much of the success of native species mixtures comes from the inclusion of wildflowers (Morrison 1981; Byler et al. 1993; Ahern et al. 1992), but there is limited research on the use of additional species (e.g., Skousen, Venable 2008).

Nonnative species are used in revegetation projects because of the ability of grasses to establish quickly and provide almost immediate erosion control. Current West Virginia regulations for permanent applications include five seed mixture combinations of nine species (WVDOH 2010). The problem with these seed mixtures is that six of the species are considered invasive, and all nine are considered introduced or both native and introduced. Because these mixtures contain invasive and nonnative species, native species need to be considered.

The work described in this article evaluated common practices used in seeding and mulching at roadside locations to highlight limitations and to suggest improvements in establishing vegetation at mountainous construction sites. We assessed the use of topsoil and compared the use of a hydraulic erosion-control product and straw as mulch. The use of topsoil could improve the soil properties and in return increase vegetative cover. Alternatively, a soil deficient in the "O" horizon could limit establishment and result in a reclamation failure. Increased establishment and cover would warrant the selection of one mulch over another to reduce erosion and timeframe under state and federal permits. Last, the study evaluated experimental seed mixtures to determine the capability of a native mixture as an alternative erosion-control measure. A native mixture that could perform as well and meet current state specifications could replace current nonnative mixtures that contain invasive species, consequently reducing the introduction and spread of invasive species. The study as a whole helps to identify critical practices for states to use in their general seeding and mulching specifications.

\section{Materials and methods}

\subsection{Development of experimental seed mixtures}

The West Virginia Division of Highways (WVDOH) conducts projects based on the "Standard Specifications: Roads and Bridges," which was adopted in 2010 (WVDOH 2010). Section 652, "Seeding and mulching", outlines the approved methods, application, and materials used for seeding and mulching. Our work developed experimental seed mixtures to be considered for future projects. Seed mixtures were developed based on the evaluation of current WVDOH mixtures and recommendations by the West Virginia Division of Natural Resources (WVDNR). An experimental warm-season mixture (Table 1) and an experimental cool-season mixture (Table 2) were compared to a commonly used WVDOH seed mixture (Table 3).

Table 1. Experimental warm-season seed mixture; all species are native except for common oat

\begin{tabular}{|c|c|c|c|}
\hline Scientific name & $\begin{array}{l}\text { Common } \\
\text { name }\end{array}$ & $\begin{array}{l}\text { Rate } \\
(\mathrm{kg} / \mathrm{ha})\end{array}$ & Description \\
\hline Poaceae Avena sativa & $\begin{array}{l}\text { Common oat } \\
\text { (Spring) }\end{array}$ & 33.6 & Nurse crop \\
\hline $\begin{array}{l}\text { Poaceae Andropogon } \\
\text { gerardii }\end{array}$ & Big bluestem & 6.7 & Graminoid \\
\hline $\begin{array}{l}\text { Poaceae Elymus } \\
\text { virginicus }\end{array}$ & $\begin{array}{l}\text { Virginia } \\
\text { wildrye }\end{array}$ & 9.4 & Graminoid \\
\hline $\begin{array}{l}\text { Poaceae Agrostis } \\
\text { perennans }\end{array}$ & $\begin{array}{l}\text { Autumn } \\
\text { bentgrass }\end{array}$ & 4.1 & Graminoid \\
\hline $\begin{array}{l}\text { Poaceae Panicum } \\
\text { virgatum }\end{array}$ & Switchgrass & 7.2 & Graminoid \\
\hline $\begin{array}{l}\text { Poaceae Sorghastrum } \\
\text { nutans }\end{array}$ & Indiangrass & 15.7 & Graminoid \\
\hline $\begin{array}{l}\text { Fabaceae } \\
\text { Chamaecrista } \\
\text { fasciculata }\end{array}$ & Partridge pea & 1.1 & Legume \\
\hline $\begin{array}{l}\text { Asteraceae } \\
\text { Rudbeckia hirta }\end{array}$ & $\begin{array}{l}\text { Black-eyed } \\
\text { Susan }\end{array}$ & 0.67 & Forb \\
\hline $\begin{array}{l}\text { Lamiaceae } \\
\text { Pycnanthemum } \\
\text { tenuifolium }\end{array}$ & $\begin{array}{l}\text { Narrowleaf } \\
\text { mountainmint }\end{array}$ & 0.11 & Forb \\
\hline $\begin{array}{l}\text { Lamiaceae Monarda } \\
\text { fistulosa }\end{array}$ & $\begin{array}{l}\text { Wild } \\
\text { Bergamot }\end{array}$ & 0.56 & Forb \\
\hline $\begin{array}{l}\text { Fabaceae Desmodium } \\
\text { paniculatum }\end{array}$ & $\begin{array}{l}\text { Panicledleaf } \\
\text { ticktrefoil }\end{array}$ & 0.45 & Forb \\
\hline $\begin{array}{l}\text { Asteraceae Heliopsis } \\
\text { helianthoides }\end{array}$ & Smooth oxeye & 0.45 & Forb \\
\hline $\begin{array}{l}\text { Asteraceae Euthamia } \\
\text { graminifolia }\end{array}$ & $\begin{array}{l}\text { Flat-top } \\
\text { goldentop }\end{array}$ & 0.11 & Forb \\
\hline
\end{tabular}

Notes: All species are perennial except the common oat (annual). 
Table 2. Experimental cool-season seed mixture (non-native seed mixture)

\begin{tabular}{llclc}
\hline \multicolumn{1}{c}{ Scientific Name } & $\begin{array}{c}\text { Common } \\
\text { Name }\end{array}$ & $\begin{array}{c}\text { Rate (kg/ } \\
\text { ha) }\end{array}$ & $\begin{array}{l}\text { Descrip- } \\
\text { tion }\end{array}$ & $\begin{array}{c}\text { Threat } \\
\text { Level }\end{array}$ \\
\hline $\begin{array}{l}\text { Poaceae Agrostis } \\
\text { gigantea }\end{array}$ & Redtop & 4.5 & $\begin{array}{l}\text { Nurse } \\
\text { crop }\end{array}$ & 3 \\
\hline $\begin{array}{l}\text { Poaceae Festuca } \\
\text { ovina var. } \\
\text { duriuscula }\end{array}$ & $\begin{array}{l}\text { Hard } \\
\text { fescue } \\
\text { "Heron" }\end{array}$ & 11.2 & $\begin{array}{l}\text { Grami- } \\
\text { noid }\end{array}$ & $\begin{array}{l}\text { Intro- } \\
\text { duced }\end{array}$ \\
\hline $\begin{array}{l}\text { Poaceae Festuca } \\
\text { brevipila }\end{array}$ & $\begin{array}{l}\text { Hard } \\
\text { fescue } \\
\text { "Chariot" }\end{array}$ & 11.2 & $\begin{array}{l}\text { Grami- } \\
\text { noid }\end{array}$ & $\begin{array}{l}\text { Intro- } \\
\text { duced }\end{array}$ \\
\hline $\begin{array}{l}\text { Poaceae Festuca } \\
\text { rubra }\end{array}$ & $\begin{array}{l}\text { Creeping } \\
\text { red fescue }\end{array}$ & 17.9 & $\begin{array}{l}\text { Grami- } \\
\text { noid }\end{array}$ & $\begin{array}{l}\text { Intro- } \\
\text { duced }\end{array}$ \\
\hline $\begin{array}{l}\text { Fabaceae } \\
\text { Trifolium repens }\end{array}$ & $\begin{array}{l}\text { White } \\
\text { clover }\end{array}$ & 7.8 & Legume & 3 \\
\hline $\begin{array}{l}\text { Fabaceae Lotus } \\
\text { corniculatus }\end{array}$ & $\begin{array}{l}\text { Birdsfoot } \\
\text { trefoil }\end{array}$ & 9.0 & Legume & 3 \\
\hline
\end{tabular}

Notes: All species are perennial except redtop (annual).

Table 3. West Virginia Division of Highways seed mixture (non-native seed mixture)

\begin{tabular}{|c|c|c|c|c|}
\hline $\begin{array}{l}\text { Scientific } \\
\text { Name }\end{array}$ & $\begin{array}{l}\text { Common } \\
\text { Name }\end{array}$ & $\begin{array}{l}\text { Rate } \\
\text { (kg/ha) }\end{array}$ & $\begin{array}{l}\text { Descrip- } \\
\text { tion }\end{array}$ & $\begin{array}{c}\text { Threat } \\
\text { Level }\end{array}$ \\
\hline $\begin{array}{l}\text { Poaceae } \\
\text { Schedonorus } \\
\text { phoenix }\end{array}$ & $\begin{array}{l}\text { Kentucky } \\
31 \text { fescue }\end{array}$ & 72.9 & $\begin{array}{l}\text { Grami- } \\
\text { noid }\end{array}$ & 1 \\
\hline $\begin{array}{l}\text { Poaceae } \\
\text { Festuca rubra } \\
\text { L. }\end{array}$ & $\begin{array}{l}\text { Red fescue } \\
\text { (Pennlawn) }\end{array}$ & 22.4 & $\begin{array}{l}\text { Grami- } \\
\text { noid }\end{array}$ & Introduced \\
\hline $\begin{array}{l}\text { Fabaceae } \\
\text { Trifolium } \\
\text { repens }\end{array}$ & $\begin{array}{l}\text { White } \\
\text { Dutch } \\
\text { clover }\end{array}$ & 3.4 & Legume & 3 \\
\hline $\begin{array}{l}\text { Poaceae } \\
\text { Eragrostis } \\
\text { curvula }\end{array}$ & $\begin{array}{l}\text { Weeping } \\
\text { lovegrass }\end{array}$ & 3.4 & $\begin{array}{l}\text { Nurse } \\
\text { crop }\end{array}$ & 3 \\
\hline
\end{tabular}

Notes: All species are perennial except weeping lovegrass (annual).

The commonly used WVDOH seed mixture (Table 3) is often successful in providing ground cover. It includes Kentucky 31 fescue (Schedonorus phoenix), which is a threat-level-1 species because it establishes and spreads rapidly and may disrupt ecosystem processes and plant community composition (WVDNR Natural Heritage Program 2009). Because the reduction of the use of invasive species on future reclamation projects is desired, experimental seed mixtures were developed for this project.

The experimental warm- and cool-season mixtures contained a nurse crop, graminoids, and legumes. In addition, the warm-season mixture included forbs. All threatlevel-1 species as defined by WVDNR Natural Heritage Program (2009) were avoided because of their invasive nature. The following list of criteria was used for species selection:

- Native or nonnative with low invasive characteristics.

- Occurs in multiple ecoregions.

- Occurs frequently in West Virginia (50-75\% county occurrence).

- Used for erosion control.

- Competitive native species pricing or low-cost nonnative species.

- Seed available by multiple distributors.

Ernst Seed's horticulturist Mark Fiely (personal communication, Jan. 13-29, 2015) and Natural Heritage Vegetation Ecologist Elizabeth A. Byers (personal communication, 8 Oct. - 5 Dec. 2014) helped recommend species for selection.

Both the warm- and cool-season experimental mixtures were designed to fulfill specific reclamation objectives. The warm-season mixture was composed of native species to inhabit cut and fill slopes (Table 1). This native mixture is intended for spring planting and to provide a positive ecological impact by avoiding the use of nonnative species. The mixture is composed of species with large foliage and root growth to interlock the slopes and prevent erosion. The cool-season mixture was developed for coolseason plantings by using minimally invasive, nonnative species (Table 2). Native species were not included because they do not have a short enough germination period to establish in the fall. The cool-season nonnative species, however, have a short germination period, which makes them suitable for late summer and early fall plantings.

\subsection{Field testing}

A plot study was completed comparing the vegetation established during one growing season (May-October 2015). Treatments included varying combinations of seed mixture, topsoil treatment, and mulch. Specific methods are reported in the following sections.

\subsubsection{Field plot setup}

Seed mixtures and bed preparation techniques were fieldtested in a plot study beside a truck ramp off U.S. 48 in West Virginia, USA (N39 $13^{\prime} 40.7^{\prime \prime}$ W79'9'44.0”). The site had a slope of $15.4 \%$, elevation of $560 \mathrm{~m}$, and slope exposure of $170^{\circ}$ (south).

Two replications of the treatments were represented within 24 subplots $(1.75 \times 1.83 \mathrm{~m})$. Treatments were formed from a combination of seed mixture (WVDOH, experimental cool-season, and experimental warm-season), topsoil treatment (topsoil or no topsoil), and type of mulch (straw or hydraulic erosion-control product, HP). Randomization was conducted to assign treatments as shown in Figure 1. 


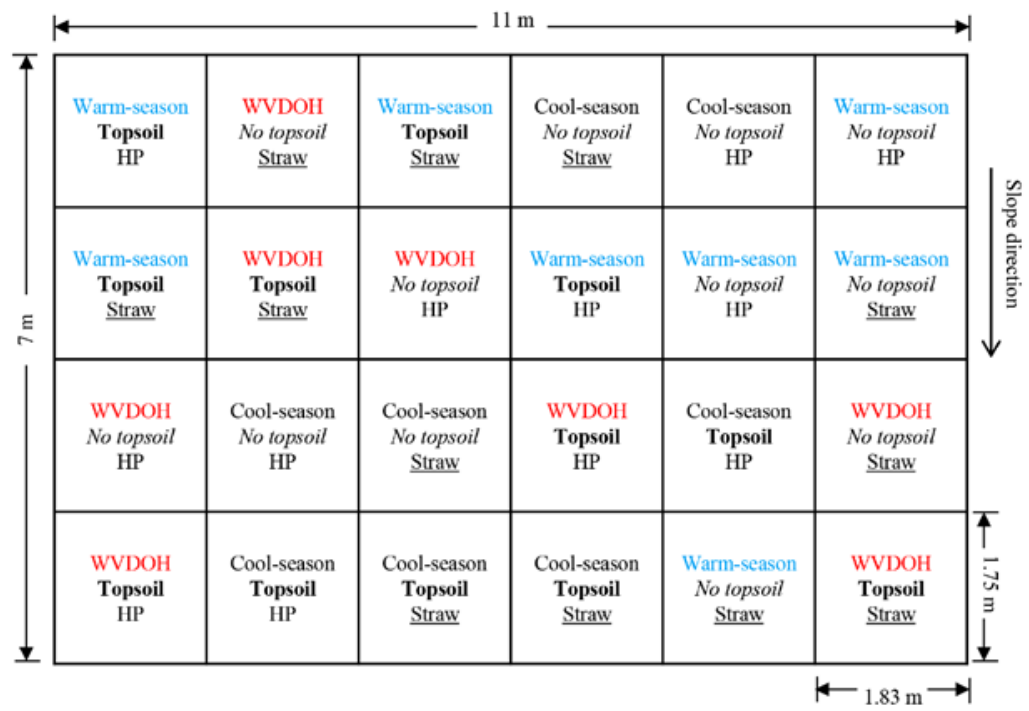

Fig. 1. Subplot layout specifying seed mixture type, soil preparation technique, and mulch used (HP - hydraulic erosion-control product)

\subsubsection{Field plot preparation}

On April 17, 2015, black plastic was placed over the entire plot area $\left(77 \mathrm{~m}^{2}\right)$ to kill the existing vegetation (Fig. 2a). Final vegetation removal was performed on May 15, 2015, by removing the dead vegetation with steel garden rakes. The black plastic was re-installed until seedbed preparation and planting occurred.

Seedbed preparation began on May 19, 2015. The soil was lightly tilled using a Honda FRC800 tiller, and all rock and debris greater than $0.05 \mathrm{~m}$ were removed by hand in accordance to the WVDOH 652 specifications (WVDOH 2010). In topsoil-designated subplots, approximately 0.076 $\mathrm{m}$ of the existing base material was removed and placed on an adjacent subplot designated as a no-topsoil treatment (Fig. 2b). An approximate depth of $0.15 \mathrm{~m}$ of topsoil was then added to the topsoil subplots. All subplots were levelled and compacted with a $136 \mathrm{~kg}$ ( $300 \mathrm{lb}$ ) Sakai PF150 plate compactor. This compaction mimicked earthwork construction. Finally, the soil surface was scarified using a steel garden rake to a depth of $0.01-0.03 \mathrm{~m}$ (Fig. 2c).

Fertilizer rates were determined from soil tests. $2.15 \mathrm{~kg}$ of $10-10-10$ fertilizer was applied to the no-topsoil area. Initially, $0.09 \mathrm{~kg}$ of 10-10-10 fertilizer was applied to the topsoil area, but this rate was corrected with an additional $3.9 \mathrm{~kg}$ after mulching. No lime was added because of the results of the soil tests reported a $\mathrm{pH}$ of 8.1, indicating that lime was not needed. Seed-mixture application followed the rates shown in Tables 1-3. Each subplot received a mixture weight of $32.66 \mathrm{~g}, 25.68 \mathrm{~g}$, or $29.73 \mathrm{~g}$ for the WVDOH, warm-season, and cool-season mixtures, respectively. A steel garden rake was used to scuff the surface to promote seed-to-soil contact after the seeds were applied.

Arnold's Custom Seeding, LLC (ACS) applied the hydraulic erosion-control product (ProMatrix ${ }^{\mathrm{TM}}$ Engineered Fiber Matrix, Profile Products) to the HP plots identified in Figure 1 at a rate of 3,400 kg/ha. Approximately $17 \mathrm{~kg}$ of straw was applied over twelve straw subplots (Fig. 2d). Tornado Tack ${ }^{\mathrm{TM}}$ ST-1000 (Profile Products) was then applied on the straw at a rate of $560 \mathrm{~kg} / \mathrm{ha}$ (Fig. 2e).

\subsection{Data collection and analysis}

Each site was instrumented with a WatchDog Tipping Bucket Rain Gauge, WaterScout SMEC 3000, and WatchDog 1425 Micro Station. Air temperature, precipitation, soil temperature, and soil moisture content were continuously monitored. Data were recorded hourly and downloaded every two weeks. (a)

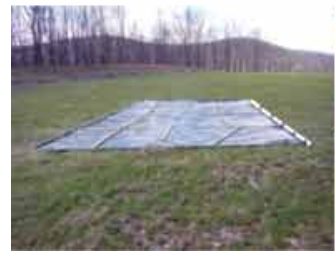

(b)

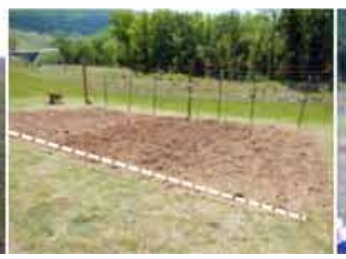

(c)

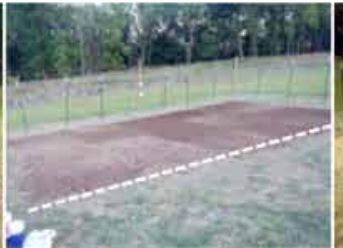

(d)

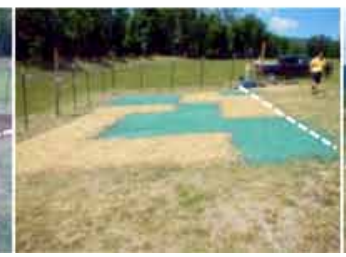

(e)

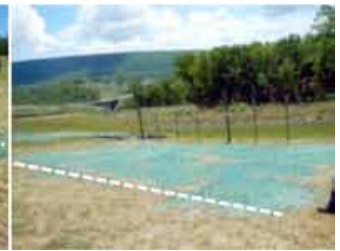

Fig. 2. Progression of site preparation: (a) spring vegetation kill, (b) topsoil placement, (c) after compaction and scarifying, (d) hydraulic mulch and straw application, (e) added tackifier (dashed line denotes the upslope location) 
Ground cover was examined in each subplot by using a $1 \times 1 \mathrm{~m}$ portable point frame with a grid containing 100 intersections, following procedures by Calloudon et al. (1996) and Elzinga et al. (1998). Each intersection was classified as vegetated or not vegetated, resulting in a ground-cover value that reported the percent area covered by vegetation. Measurements were conducted approximately every two weeks after planting, and the portable point frame was positioned in the same location within the subplot for each measurement. Concurrently, pictures were taken to identify ground cover by species.

A biomass sample was collected from each subplot at the end of the growing season. The aboveground biomass was clipped at the soil surface with grass shears from a $0.09 \mathrm{~m}^{2}$ area. The area of clipping was randomly placed in the $3.2 \mathrm{~m}^{2}$ subplot area. The biomass was divided into categories of planted species and not planted species and weighed in the field (SERAS 1994; Franks, Goings 2016).

A soil sample (top $15.2 \mathrm{~cm}$ ) was collected from each subplot at the end of the growing season. Samples from common treatments were combined and thoroughly mixed. The composite samples were analysed by AgSource Laboratories-Harris (Lincoln, Nebraska) for organic matter $(\mathrm{OM}), \mathrm{pH}, \mathrm{N}, \mathrm{P}$, and $\mathrm{K}$. Analytical procedures followed the methods reported by AgSource (2006). An agraTronix Soil Compaction Tester (Streetsboro, $\mathrm{OH}$ ) was used to test the compaction of the subplots (ASABE S313.3; ASAE EP542). Compaction was tested once at the planting stage and once at the end of the study. Erosion factors were visually inspected and recorded during each visit.

One-way blocked analysis of variance examined whether there were any statistical differences in percent cover among seed mixtures and treatments (Lyman, Longnecker 2001). JMP Pro software (v.12.0.1, SAS Institute, Cary, NC) was used for all statistical analyses.

\section{Results and discussion}

It is important to achieve $70 \%$ ground cover within a growing season because this level of cover is needed in the disturbed area to terminate the National Pollutant Discharge Elimination System (NPDES) general water-pollution-control permit (WVDOH 2003; USEPA 2007). This value was considered when evaluating the results. Regardless of bed preparation technique, all WVDOH plots, as well as all subplots without topsoil, achieved at least $70 \%$ cover within 34 days. The plots with topsoil were slightly delayed likely because of insufficient fertilizer application that was corrected 29 days after planting. With this correction, all plots reached the $70 \%$ target quickly, with all sites having at least $70 \%$ cover after 51 days (Fig. 3). The ground cover remained greater than $70 \%$ for the rest of the growing season for all plots.

Climatic conditions were generally positive for seed germination (Figs 4-6), so observed differences are likely due to soil preparation and seed selection. For example, there were at least eight storms contributing greater than $1 \mathrm{~cm}$ of rain in May and June. Typically, a depth of $0.64 \mathrm{~cm}$ of rain is an adequate (Steinfeld et al. 2007). The volumetric moisture content of soil was also elevated during that period (Fig. 5). Soil temperatures were within typical ranges for germination, shoot growth, and root growth (Fig. 6); however, soil temperature was more favorable for warm-season species that have optimal ranges of

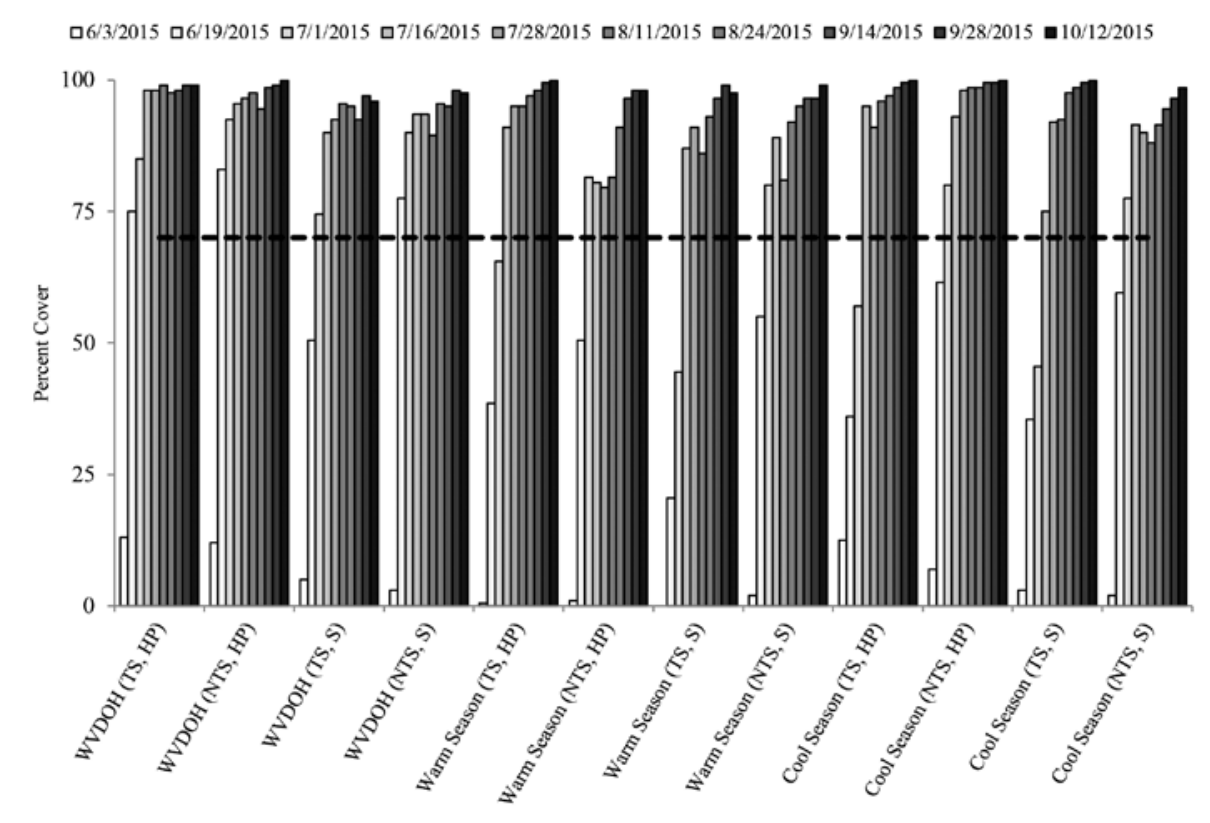

Fig. 3. Average ground cover over the course of the study period; the dashed line represents $70 \%$ cover needed to terminate the National Pollutant Discharge Elimination System permit (TS topsoil, NTS - no topsoil, HP - hydraulic erosion-control product, $\mathrm{S}$ - straw) 
soil temperatures of $20-35^{\circ} \mathrm{C}, 27-35^{\circ} \mathrm{C}$, and $24-29^{\circ} \mathrm{C}$ for germination, shoot growth, and root growth, respectively. Optimal ranges of temperatures for cool-season grasses are $15-20^{\circ} \mathrm{C}, 16-23^{\circ} \mathrm{C}$, and $10-18{ }^{\circ} \mathrm{C}$ for germination, shoot growth, and root growth, respectively (Beard 1973).

Because it is important to establish ground cover quickly, differences in ground cover were examined after eight days. There were significant differences among both seed mixtures and bed-preparation techniques ( $\mathrm{p}$-values = 0.002 and 0.013 , respectively). The warm-season seed mixture did not perform to the same level as the cool-season and WVDOH mixtures (Table 4). The native warm-season mixture was characterized by species that have slower

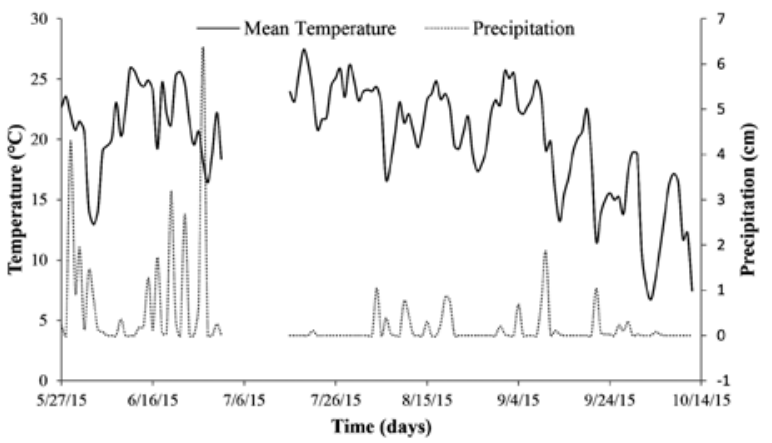

Fig. 4. Mean air temperature and precipitation at the field site; data are missing because of a malfunction of field-download

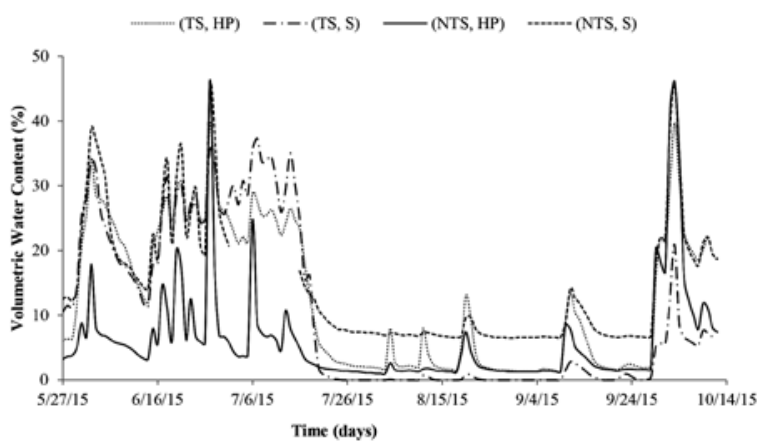

Fig. 5. Soil volumetric water content in four subplots: (1) TS, HP; (2) TS, S; (3) NTS, S; and, (4) NTS, S. (TS - topsoil, NTS - no topsoil, HP - hydraulic erosion-control product, $\mathrm{S}-$ straw)

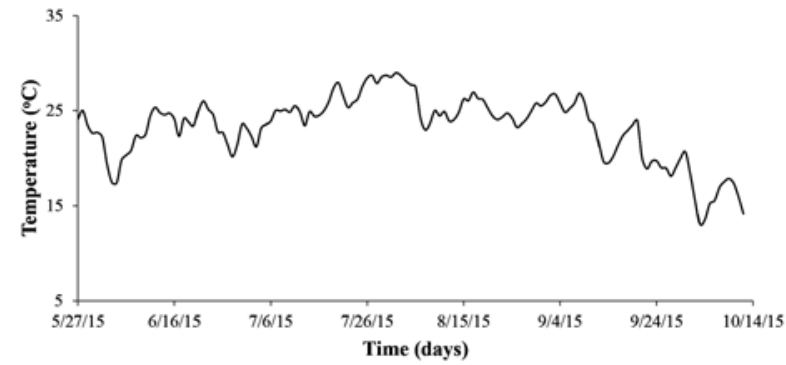

Fig. 6. Mean soil temperature over the duration of the field study germination rates compared to nonnative cool-season species (Salon, Miller 2012) in the cool-season and WVDOH mixtures. Treatments with the hydraulic mulch (HP) had significantly higher ground cover compared to treatments with straw (S) early in the study (Table 5).

Results suggest that native or low-threat-level species can be included in future seed mixtures for roadside sites and provide a similar level of protection compared to current methods. There was no statistical difference among the tested seed mixtures and bed-preparation treatments

Table 4. Ground cover at the beginning and end of the growing season for all tested seed mixtures; total biomass and biomass of planted species of the three seed mixtures at the end of the growing season (SD - standard deviation)

\begin{tabular}{lcccccccc}
\hline \multirow{2}{*}{$\begin{array}{c}\text { Seed } \\
\text { Mixture }\end{array}$} & $\begin{array}{c}\text { Time } \\
(\text { days) }\end{array}$ & \multicolumn{2}{c}{$\begin{array}{c}\text { Ground } \\
\text { Cover }(\%)\end{array}$} & \multicolumn{2}{c}{$\begin{array}{c}\text { Total } \\
\text { Biomass } \\
(\mathrm{mg})\end{array}$} & \multicolumn{3}{c}{$\begin{array}{c}\text { Biomass } \\
\text { of planted } \\
\text { species }\end{array}$} \\
\cline { 3 - 9 } & & Mean & SD & Mean & SD & Mean & SD \\
\hline WVDOH & 8 & 8.3 & 5.7 & - & - & - & - \\
\hline $\begin{array}{l}\text { Warm } \\
\text { season }\end{array}$ & 8 & 0.9 & 1 & - & - & - & - \\
\hline $\begin{array}{l}\text { Cool } \\
\text { season }\end{array}$ & 8 & 6.1 & 4.8 & - & - & - & - \\
\hline WVDOH & 139 & 98.1 & 1.8 & 42.3 & 12.8 & 23.3 & 16.4 \\
\hline $\begin{array}{l}\text { Warm } \\
\text { season }\end{array}$ & 139 & 98.6 & 1.3 & 65.1 & 35.3 & 49.4 & 42.3 \\
\hline $\begin{array}{l}\text { Cool } \\
\text { season }\end{array}$ & 139 & 99.6 & 0.7 & 97.6 & 12.4 & 80.3 & 21.9 \\
\hline
\end{tabular}

Table 5. Ground cover at the beginning and end of the growing season for the seedbed preparation treatments; total biomass and biomass of planted species at the end of the growing season compared by seedbed preparation treatment (SD standard deviation)

\begin{tabular}{lccccccc}
\hline \multirow{2}{*}{$\begin{array}{l}\text { Treat- } \\
\text { ment }\end{array}$} & $\begin{array}{c}\text { Time } \\
(\text { days })\end{array}$ & $\begin{array}{c}\text { Ground } \\
\text { Cover }(\%)\end{array}$ & $\begin{array}{c}\text { Total Biomass } \\
(\mathrm{mg})\end{array}$ & \multicolumn{3}{c}{$\begin{array}{c}\text { Biomass } \\
\text { of planted } \\
\text { species }(\mathrm{mg})\end{array}$} \\
\cline { 3 - 8 } $\begin{array}{l}\text { TS, } \\
\text { HP }\end{array}$ & 8 & 8.7 & 7.3 & - & - & - & - \\
\hline NTS, & 8 & 6.7 & 5.3 & - & - & - & - \\
HP & 85 & Mean & SD & Mean & SD \\
\hline TS, S & 8 & 2.7 & 2.7 & - & - & - & - \\
\hline $\begin{array}{l}\text { NTS, } \\
\text { S }\end{array}$ & 8 & 2.3 & 1.5 & - & - & - & - \\
\hline $\begin{array}{l}\text { TS, } \\
\text { HP }\end{array}$ & 139 & 99.7 & 0.8 & 67 & 31.4 & 39.7 & 34.2 \\
\hline $\begin{array}{l}\text { NTS, } \\
\text { HP }\end{array}$ & 139 & 99.3 & 1.2 & 65.3 & 29.6 & 59.3 & 31.7 \\
\hline TS, S & 139 & 97.8 & 1.9 & 59.2 & 30.3 & 24.8 & 18.9 \\
\hline $\begin{array}{l}\text { NTS, } \\
\text { S }\end{array}$ & 139 & 98.3 & 1 & 82 & 39.2 & 80 & 39.5 \\
\hline
\end{tabular}

Notes: TS - topsoil, NTS - no topsoil, S - straw, HP - hydraulic erosion control product. 
after 139 days ( $\mathrm{p}$-values $=0.260$ and 0.551 , respectively, Table 5). The warm-season mixture was able to perform to the same level as the cool-season and WVDOH mixtures in long-term establishment (Table 4).

There were no significant differences among bed preparation techniques when considering total biomass at the end of the growing season $(\mathrm{p}$-value $=0.377$ ), but there were differences in tested seed mixtures ( $\mathrm{p}$-value $=$ 0.0005) (Tables 4-5). The total biomass of the cool-season mixture was greater than the WVDOH and warm-season mixtures. The WVDOH mixture had the most weed species by weight, and the cool-season mixture had the fewest weeds. The likely reason for a high level of weed species is the low diversity of the WVDOH mixture (number of species $=4$ ). Mixtures with a larger variety of species help prevent invasive or weed species from establishing (Oakley, Knox 2013). The WVDOH mixture primarily resulted in the establishment of weeping lovegrass (Eragrostis curvula). This graminoid is an annual species that could completely die off if re-seeding does not occur. Ultimately, the WVDOH mixture is at risk of greater ground coverage by weed species because a larger area would be available for establishment during the following growing season. Further site examination will verify the succession of the mixture.

Typically soils are added to cuts, but such soils are thinner with less available water and fewer nutrients than native soils (Rentch et al. 2005); the use of topsoil is recommended to promote desired soil properties (e.g., WVDOH 2010). Alday et al. (2011) found that native vegetation communities develop more than twice as fast on surface coal-mining reclamation sites when topsoil is added as compared to sites without topsoil. Mola et al. (2011) reported that improving top soil quality will improve vegetation cover when seeding occurs outside of the optimal season. Therefore, it was expected that the topsoil would improve vegetation germination and persistence, but for total cover, the topsoil plots exhibited few differences from plots without topsoil (Table 5).

Competition introduced by topsoil may reduce success of establishing native vegetation. Ground cover by species was examined 90 days after planting. The notplanted cover ranged between $41 \%$ and $84 \%$ for treatments with topsoil and $0 \%$ and $17 \%$ in treatments without topsoil (Fig. 7). The high percentage of introduced species was likely due to the topsoil containing high levels of seed that was not destroyed or removed by the producer. The most prevalent introduced species was barnyardgrass (Echinochloa crus-galli), which is not native to West Virginia. The selection of topsoil is important to control the composition of vegetation. Even locally sourced topsoil can be laced with invasive or undesirable species, as in this case. If outsourcing topsoil is required, priority should be directed to ensure a weed-free product. Otherwise, a project could be overrun with invasive or weed species resulting in timely and costly maintenance to remove the undesirable species.

There were no differences found in the amount of introduced species within straw plots as compared to the plots with hydraulic erosion-control product, but straw has limitations. Hydraulic mulch with a tackifier can completely cover a soil surface and bind to the soil surface to provide protection against erosion. Hydraulic mulch without a tackifier is not recommended because the adhesion to the soil surface and product are important for erosion control. In contrast, straw mulch does not come into complete contact with the soil surface the way hydraulic mulch does. If straw is not tacked during application, as is frequently observed in practice, the mulch is prone to dispersion by wind and rain. Straw mulch without tackifier

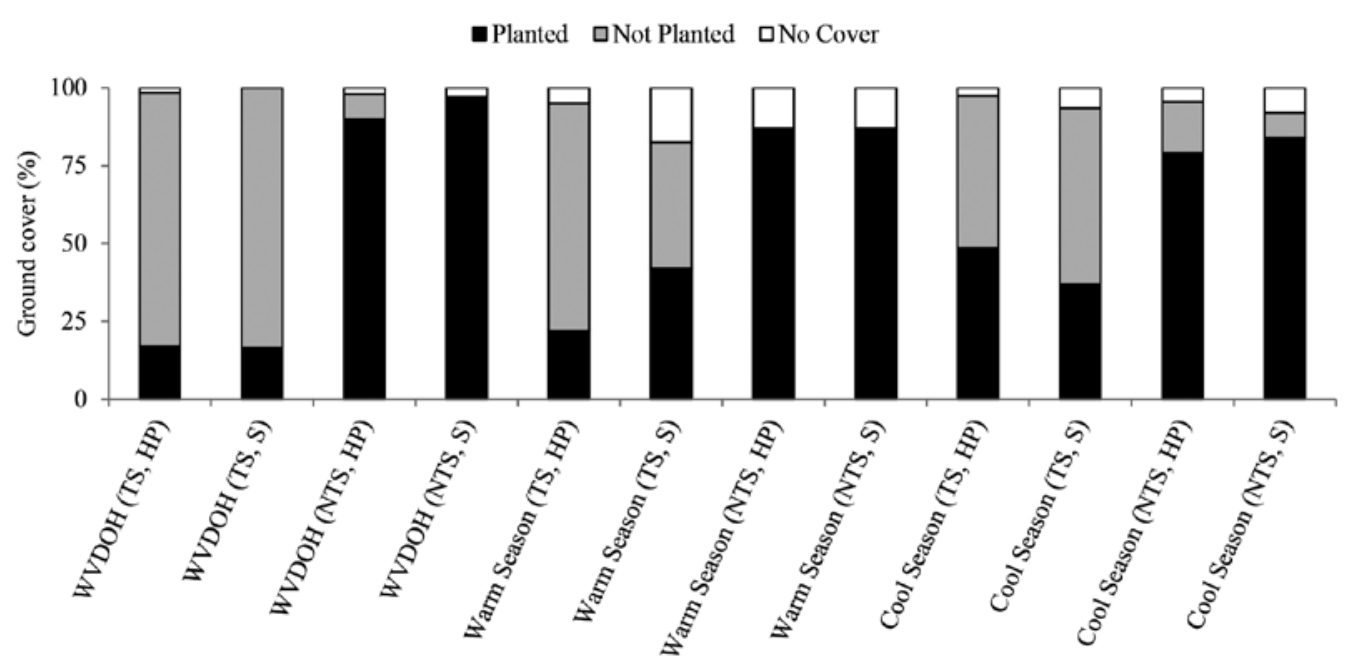

Fig. 7. Ground cover by planted species at 90 days (TS - topsoil, NTS, no topsoil, HP - hydraulic erosion control product, $\mathrm{S}-$ straw) 
applied on a reclamation site north of the study blew away in less than eight days, resulting in a completely bare soil surface. Some remnants of the straw were entangled in an adjacent fence, indicating the importance of a tackifier for straw mulch application. Without a tackifier, the soil would be exposed and vulnerable to erosion and sediment detachment.

The upper few inches of compacted soil have the most influence on growth (Beard 1973). To promote plant establishment and root development, an over compacted soil should be fractured between 23 and $30 \mathrm{~cm}$ (Salon, Miller 2012). Before seedbed preparation, the top $22.8 \mathrm{~cm}$ of the plot was severely compacted, which would have hindered root development. After site preparation (i.e., tilling, compacting, scarifying, moving soil), the first $7.6 \mathrm{~cm}$ of the topsoil subplots improved and would provide optimum compaction conditions. Subplots with no topsoil (NTS) generally had higher compaction, but the results still indicated moderate conditions for root development. Half of the subplots displayed poor compaction conditions at a depth of $15.2 \mathrm{~cm}$; the remaining subplots showed severe conditions. At a depth of $22.8 \mathrm{~cm}$, all subplots were overly compacted (i.e., severe conditions) regardless of bed preparation technique (Table 6).
For the long-term, vegetation systems should become self-sustaining (Coppin, Richards 1990). In general, soil conditions in our study were generally constant (Table 7). There was one exception. The nitrogen in the no topsoil, hydraulic erosion control product plot more than tripled, and these changes were unexpected. The tests were completed on a site that was previously limed, fertilized, and seeded according to WVDOH regulations; therefore, few soil amendments were needed. It was expected that the topsoil would improve organic matter levels. The topsoil obtained from Grant County Mulch Inc., a local producer, met the minimum standards for topsoil but provided few benefits. The cost of including topsoil in reclamation projects is substantial. The use of various soil-amendment and media products is a possible solution to limited or expensive topsoil application. These products are designed to improve and promote the development of an "O" horizon and biological activity within the soil by introducing organic matter and other components while promoting the establishment and development of vegetation. These products are not a true replacement for topsoil, but instead offer an alternative solution when faced with project constraints.

Table 6. Compaction information for subplots; severe conditions noted in italics

\begin{tabular}{|c|c|c|c|c|c|c|c|c|c|}
\hline & \multicolumn{3}{|c|}{ WVDOH } & \multicolumn{3}{|c|}{ Warm Season } & \multicolumn{3}{|c|}{ Cool Season } \\
\hline & \multicolumn{3}{|c|}{ Depth $(\mathrm{cm})$} & \multicolumn{3}{|c|}{ Depth $(\mathrm{cm})$} & \multicolumn{3}{|c|}{ Depth $(\mathrm{cm})$} \\
\hline & $0-7.6$ & $7.6-15.2$ & $15.2-22.8$ & $0-7.6$ & $7.6-15.2$ & $15.2-22.8$ & $0-7.6$ & $7.6-15.2$ & $15.2-22.8$ \\
\hline $\begin{array}{l}\text { Before site } \\
\text { preparation }\end{array}$ & 0 & 0 & 0 & 0 & 0 & 0 & 0 & 0 & 0 \\
\hline \multicolumn{10}{|l|}{$\begin{array}{l}\text { After site } \\
\text { preparation }\end{array}$} \\
\hline TS, HP & 2.5 & 0.5 & 0 & 3 & 0.75 & 0.25 & 2.5 & 1.25 & 0.5 \\
\hline NTS, HP & 2 & 0.5 & 0 & 2 & 0.5 & 0 & 1.5 & 0.5 & 0 \\
\hline TS, S & 3 & 1 & 0.5 & 3 & 1.75 & 0.25 & 2.5 & 0.5 & 0 \\
\hline NTS, S & 2.5 & 0.75 & 0.2 & 2 & 0.5 & 0 & 2.5 & 0.75 & 0.25 \\
\hline
\end{tabular}

Notes: 0-0.5 - severe; 0.6-1.0 - poor; 1.1-2.0 - moderate; 2.1-3.0 - optimal; TS - topsoil, NTS - no topsoil; S - straw; HP - hydraulic erosion control product.

Table 7. Soil analysis results

\begin{tabular}{|c|c|c|c|c|c|c|}
\hline & Treatment & OM (\%) & $\mathrm{N}(\mathrm{ppm})$ & $\mathrm{P}(\mathrm{ppm})$ & $\mathrm{K}(\mathrm{ppm})$ & $\mathrm{pH}$ \\
\hline \multirow{2}{*}{$\begin{array}{l}\text { Before site } \\
\text { preparation } \\
(04 / 11 / 2015)\end{array}$} & composite & 1.0 & 2.6 & 7 & 79 & 8.1 \\
\hline & topsoil & 1.8 & 6.0 & 5 & 55 & 6.7 \\
\hline \multirow{4}{*}{$\begin{array}{l}\text { At end of } \\
\text { growing season } \\
(10 / 29 / 2015)\end{array}$} & TS, HP & 2.1 & 2.4 & 3 & 76 & 7.6 \\
\hline & TS, S & 1.8 & 2.8 & 2 & 80 & 7.7 \\
\hline & NTS, S & 1.8 & 2.4 & 5 & 96 & 7.7 \\
\hline & NTS, HP & 1.8 & 9.4 & 7 & 113 & 7.7 \\
\hline
\end{tabular}

Notes: TS - topsoil, NTS - no topsoil; S - straw; HP - hydraulic erosion control product. 


\section{Conclusions}

This plot study evaluated experimental seed mixtures and multiple bed preparation techniques at a roadside location in mountainous terrain. The intent was to identify critical practices to use in general seeding and mulching specifications related to seed selection, topsoil use, and mulching. We found that native or low-threat species could be included in roadside revegetation specifications, that topsoil might not provide the intended benefits if it is of low quality, and that hydraulic erosion-control products should be used when quick germination is desired. Conclusions from this research include the following:

- Two experimental seed mixtures are presented that will aid in limiting the spread of invasive species. The warm-season mixture was composed primarily of native species, and the cool-season mixture was composed of primarily low-threat-level species. When compared to the currently used mixture, the experimental seed mixtures achieved the target $70 \%$ cover required to terminate the environmental permit within 12 to 27 days. This result suggests that native and low-threat-level species can be included in future seed mixtures for roadside sites, while providing the similar level of protection compared to currently used methods.

- It was expected that topsoil would improve vegetation establishment. While improvements in soil compaction were detected with the addition of topsoil, few agronomic enhancements were observed. Considering total ground cover and biomass, no statistical differences were noted between topsoil and no topsoil plots. Also, topsoil introduced a substantial amount of undesirable weed species, suggesting that specifications for topsoil harvesting are critical in practice if the persistence of native species is desired. Future specifications should consider the use of soil amendment and media products to introduce organic matter. As these products are relatively new, there is often limited ability to incorporate them into roadside projects with in the use of current specifications.

- Few differences were observed between the use of straw and the hydraulic erosion-control product. The main difference was that faster germination was observed in the plots with the hydraulic erosion-control products. Therefore, if initial establishment is desired, a hydraulic product could be favourable over traditional mulch like straw. The field plot was moderately sloping, so the full benefits of the hydraulic erosion-control product were not likely observed in this study.

Future studies should examine these seed mixtures, mulch applications, and seedbed preparation measures at a large scale. For alternative topsoil solutions, various soil-amendment and media products should be examined to test vegetation establishment, composition, and persistence.

\section{Acknowledgements}

We would like to thank the following contributions to the project. Mark Fiely (Ernst Conservation Seeds); Elizabeth Byers (WVDNR); and, Casey Shrader and Sonya Keith (NRCS in Lexington, KY) reviewed the proposed seed mixtures. Charlie Riling, Donald Williams, and Michael Pumphrey (WVDOH) assisted in field site selection and provided general guidance. Kenneth Friedman reviewed a previous version of this manuscript. Dustin Buckalew and additional representatives of Arnold's Custom Seeding donated time and equipment to apply the hydraulic erosion-control products. Steve Zwilling, Adam Dibble, and Matt Welch with Profile Products donated products (ProMatrix $^{\mathrm{TM}}$ Engineered Fiber Matrix and Tornado Tack ${ }^{\mathrm{TM}}$ ), time and expertise in applying the products.

\section{Funding}

The contents of this report reflect the views of the author who is responsible for the facts and the accuracy of the data presented here. The contents do not necessarily reflect the official views or policies of the state. This report does not constitute a standard, specification, or regulation. Trade or manufacturers' names that may appear are cited only because they are considered essential to the objectives of this report. The state of West Virginia does not endorse products or manufacturers. Prepared for the West Virginia Department of Transportation Division of Highways. Summer student researchers were supported in part by the WVU CEE SURF program.

\section{Disclosure statement}

The authors have no competing financial, professional, or personal interests from other parties.

\section{References}

AgSource. 2006. Test procedures and methods [online], [cited 29 September 2015]. AgSource Laboratories. Available from internet: http://agsource.crinet.com/page4493/TestProceduresMethods

Ahern, J.; Niedner, C.; Barker, A. 1992. Roadside wildflower meadows: Summary of benefits and guidelines to successful establishment and management, Transportation Research Record 1334: 46-53.

Alday, J. G.; Marrs, R. H.; Martinez-Ruiz, C. 2011. Vegetation succession on reclaimed coal wastes in Spain: the influence of soil and environmental factors, Applied Vegetation Science 14: 84-94. https://doi.org/10.1111/j.1654-109X.2010.01104.x 
ASABE S313.3:2013. Soil cone penetrometer. American Society of Agricultural and Biological Engineers.

ASAE EP542:1999. Procedures for using and reporting data obtained with the soil cone penetrometer. American Society of Agricultural Engineers.

Beard, J. D. 1973. Turfgrass: Science and Culture. Prentice-Hall.

Bochet, E.; Tormo, J.; Garcia-Fayos, P. 2010. Native species for roadslope revegetation: Selection, validation, and cost effectiveness, Restoration Ecology 18(5): 656-663. https://doi. org/10.1111/j.1526-100X.2008.00496.x

Brindle, F. 2002. Use of native vegetation and biostimulants for controlling soil erosion on steep terrain, Transportation Research Record 1819(1): 203-209.

Byler, B.; Coorts, G.; Cripps, R.; Swan, C. 1993. Landscaping with native plants and wildflowers on Tennessee Interstates. Tennessee Department of Transportation Report TN-RES1004, Nashville, TN.

Calloudon, B.; Eshelman, K.; Gianola, J.; Habich, N.; Hughes, L.; Johnson, C.; Pellant, M.; Podborny, P.; Rasmussen, A.; Robles, B.; Shaver, P.; Spehar, J.; Willoughby, J. 1996. Sampling vegetation attributes. Technical Reference 1734-4, U.S. Department of Agriculture, Colorado.

Coppin, N. J.; Richards, I. G. 1990. Use of vegetation in civil engineering. Construction Industry Research and Information Association, London.

Dunifon, S. N.; Evanylo, G. K.; Maguire, R. O.; Goatley, J. M. 2011. Soil nutrient and fescue (Festuca app.) responses to compost and hydroseed on a disturbed roadside, Compost Science \& Utilization 19(3): 147-151.

https://doi.org/10.1080/1065657X.2011.10736993

Elzinga, C. L.; Salzer, D. W.; Willoughby, J. W. 1998. Measuring and monitoring: plant population. Technical Reference 17301, U. S. Bureau of Land Management, Colorado.

Franks, C. D.; Goings, K. 2016. A. Above-ground biomass (plant) determinations. Natural Resources Conservation Service [online], [cited 9 February 2016]. Available from Internet: http://www.nrcs.usda.gov/Internet/FSE_DOCUMENTS/ nrcs142p2_051916.pdf

Gray, D. H.; Sotir, R. B. 1996. Biotechnical and soil bioengineering slope stabilization: a practical guide for erosion control. New York: John Wiley \& Sons.

Haan, N. L.; Hunter, M. R.; Hunter, M. D. 2012. Investigating predictors of plant establishment during roadside restoration, Restoration Ecology 20(3): 315-321.

https://doi.org/10.1111/j.1526-100X.2011.00802.x

Hargett, D. L.; Phillips, J. A.; Kleiss, H. J. 1982. Soil variability and fertility considerations affecting establishment of erosion control vegetation on Piedmont roadcuts, Journal of Soil and Water Conservation Society 37(4): 229-233.

Lyman, O. R.; Longnecker, M. 2001. Analysis of variance for standard designs, Chapter 15, in An introduction to statistical methods and data analysis. $5^{\text {th }} \mathrm{ed}$. California: Duxbury.

Mola, I.; Jimenez, M. D.; Lopez-Jimenez, N.; Casado, M. A.; Balaguer, L. 2011. Roadside reclamation outside the revegetation season: Management options under schedule pressure, Restoration Ecology 19(1): 83-92.

https://doi.org/10.1111/j.1526-100X.2009.00547.x

Morrison, D. G. 1981. Use of prairie vegetation on disturbed sites, Transportation Research Record 822: 10-17.

Mortensen, D. A.; Rauschert, S. J.; Nord, A. N.; Jones, B. P. 2009.
Forest roads facilitate the spread of invasive plants, Invasive Plant Science and Management 2(3): 191-199.

https://doi.org/10.1614/IPSM-08-125.1

NCDOT. 2003. Section 5.6.2 Permanent seeding and mulching. Best management practices for construction and maintenance Activities. North Carolina Department of Transportation, Raleigh, North Carolina.

Oakley, C. A; Knox, J. S. 2013. Plant species richness increases resistance to invasion by non-resident plant species during grassland restoration, Applied Vegetation Science 16: 21-28. https://doi.org/10.1111/j.1654-109X.2012.01202.x

Pan, C.; Shangguan, Z. 2006. Runoff hydraulic characteristics and sediment generation in sloped grassplots under simulated rainfall conditions, Journal of Hydrology 331(1): 178-185. https://doi.org/10.1016/j.jhydrol.2006.05.011

PennDOT. 1998. Section 804. Seeding and soil supplements publication 408. Pennsylvania Department of Transportation, Harrisburg, Pennsylvania.

Rentch, J. S; Fortney, R. H.; Stephenson, S. L.; Adams, H. S.; Grafton, W. N.; Anderson, J. T. 2005. Vegetation-site relationships of roadside plant communities in West Virginia, USA, Journal of Applied Ecology 42: 129-138. https://doi.org/10.1111/j.1365-2664.2004.00993.x

Robichaud, P. R.; Jordan, P.; Lewis, S. A.; Ashmun, L. E.; Covert, S. A.; Brown, R. E. 2013. Evaluating the effectiveness of wood shred and agricultural straw mulches as a treatment to reduce post-wildfire hillslope erosion in southern British Columbia, Canada, Geomorphology 197: 21-33. https://doi.org/10.1016/j.geomorph.2013.04.024

Salon, P. R.; Miller, C. F. 2012. A guide to conservation plantings on critical areas for the northeast. USDA, NRCS, Corning, N.Y.

Scientific Engineering Response and Analytical Services (SERAS). 1994. Standard operating procedure: Plant biomass determination [online], [cited 9 February 2016]. SOP\#2034. EP-W-09-031. Available from Internet: https://clu-in.org/ download/ert/2034-R00.pdf

Skousen, J. G.; Venable, C. L. 2008. Establishing native plants on newly-constructed and older-reclaimed sites along West Virginia Highways, Land Degradation and Development 19: 388-396. https://doi.org/10.1002/ldr.846

Steinfeld, D. E.; Riley, S. A.; Wilkinson, K. M.; Landis, T. D.; Riley, L. E. 2007. Roadside revegetation: An integrated approach to establishing native plants. FHWA-WFL/TD-07-005. Technology Deployment Program. Federal Highway Administration, Vancouver, WA.

Storey, B. J.; Schutt, J. R.; McFalls, J. A.; Jones, K. D.; Garza, A. P.; Gaus, T. A.; Marek, G.; Heflin, K.; Rogers, W. J.; Robinson, C. 2011. Synthesis and study of the roadside vegetation establishment process [online], [cited 26 January 2016]. Texas Department of Transportation. FHWA/TX-11/0-5731-1. $101 \mathrm{p}$. Available from Internet: http://d2dtl5nnlpfr0r.cloudfront.net/ tti.tamu.edu/documents/0-5731-1.pdf

US Environmental Protection Agency (USEPA). 2007. Developing your stormwater pollution prevention plan: a guide for construction sites [online], [cited 29 September 2015]. EPA833-R-06-004, 19. Available from Internet: http://water.epa. gov/polwaste/npdes/stormwater/upload/sw_swppp_guide. pdf

VDOT. 2007. Section 603-Seeding. Road and bridge specifications. Virginia Department of Transportation, Richmond, Virginia. 
West Virginia Division of Natural Resources (WVDNR) Natural Heritage Program. 2009. Invasive Plant Species of West Virginia [online], [cited 11 February 2015]. Available from Internet: http://www.wvdnr.gov/Wildlife/Handout\%20Invasive\%20Plants\%20of\%20WV\%202009.pdf

WVDOH. 2003. Erosion and sediment control manual [online], [cited 29 September 2015]. Available from Internet: http:// www.transportation.wv.gov/highways/ engineering/files/Erosion/Erosion2003.pdf

WVDOH. 2010. Section 652 - seeding and mulching. Standard specifications roads and bridges. West Virginia Division of Highways, Charleston, WV.

George HILVERS. He is a Civil Engineer at Langan Engineering and Environmental Services, Inc. He is a former Graduate Research Assistant in the Civil and Environmental Engineering Department at West Virginia University.

Leslie HOPKINSON. She is an Associate Professor in Civil and Environmental Engineering at West Virginia University. Her research focus is in hydrology, streambank stability, reclamation, and stream restoration.

Eric DAVIS. He is a Detailer / Project Manager for CEC Steel in Morgantown, West Virginia. He is a former Graduate Research Assistant in the Civil and Environmental Engineering Department at West Virginia University and completed two co-op positions with the West Virginia Division of Highways. 